\title{
Physiochemical Parameters Optimization for Enhanced Nisin Production by Lactococcus lactis (MTCC 440)
}

\author{
Puspadhwaja Mall ${ }^{1}$, Bijaya Kumar Mohanty ${ }^{2}$, Dhananjay Bhawanishankar Patankar ${ }^{1}$, \\ Rustom Mody ${ }^{1}$ and Rashbehari Tunga ${ }^{1 *}$ \\ ${ }^{1}$ Intas Biopharmaceuticals Ltd; 423/P/A/GIDC; Moraiya; Ahmedabad-382 210; India. ${ }^{2}$ Department of Botany and \\ Biotechnology; Khallikote Autonomous College; Berhampur; Orissa - India
}

\begin{abstract}
The influence of various physiochemical parameters on the growth of Lactococcus lactis sub sp. lactis MTCC 440 was studied at shake flask level for $20 \mathrm{~h}$. Media optimization (MRS broth) was studied to achieve enhanced growth of the organism and also nisin production. Bioassay of nisin was done with agar diffusion method using Streptococcus agalactae NCIM 2401 as indicator strain. MRS broth $(6 \%, w / v)$ with $0.15 \mu \mathrm{g} / \mathrm{ml}$ of nisin supplemented with $0.5 \%(v / v)$ skimmed milk was found to be the best for nisin production as well as for growth of L lactis. The production of nisin was strongly influenced by the presence of skimmed milk and nisin in MRS broth. The production of nisin was affected by the physical parameters and maximum nisin production was at $30^{\circ} \mathrm{C}$ while the optimal temperature for biomass production was $37^{\circ} \mathrm{C}$.
\end{abstract}

Key words: Nisin, Lactococcus lactis, Streptococcus agalactae, skimmed milk

\section{INTRODUCTION}

Nisin, a bacteriocin isolated first in 1928 from lactic acid producing micro-organism, is a naturally occurring antimicrobial peptide, discovered in 1928 (Hurst, 1967; Montville and Chen 1998). Initially, it was considered to be a conventional antibiotic; however, later it became clear that nisin was distinctive in several ways. It is a protein;,whereas most therapeutic antibiotics are not. Some 30 years after it was discovered, nisin was used commercially in England and Europe. In 1988, it was approved by the US Food and Drug administration (USFDA) for a narrow range of foods, including pasteurized egg products. It has been accepted as safe and natural preservative in more than 50 countries and is widely used as antimicrobial agent in the food industries (Cleveland et al 2001).

Nisin has been applied in food preservation (Turner et al., 2004) and dental care products (Delves-Broughton et al., 1990). Nisin inhibits spore germination and growth of Gram-positive bacteria and for this reason, it is widely used as a natural preservative (Vessoni Penna and Moraes 2002; Thomas et. al., 2002). The solubility of nisin increases with a substantial increase in acidity. Nisin is stable at $\mathrm{pH} 2.0$ and can be autoclaved at $121^{\circ} \mathrm{C}$. Nisin activity decreases with increase in $\mathrm{pH}$ but complete inactivation occurs after 30 minutes of incubation at $63^{\circ} \mathrm{C}$ and $11.0 \mathrm{pH}$ (Hansen et al., 1991).

The aim of the present work was to study the production of nisin and growth of Lactococcus

*Author for correspondence: Rashbehari.tunga@intasbiopharma.co.in 
lactis MTCC 440 in MRS broth and in other combinations of MRS broth. The effect of various physical parameters (temperature and agitation) and chemical parameters (concentration of MRS, milk and nisin) were also studied.

\section{MATERIALS AND METHODS}

\section{Bacterial strains}

In the present study, the nisin producer strain Lactococcus lactis MTCC 440 and nisin sensitive indicator strain Streptococcus agalactae NCIM 2401 were used. The cultures were revived in MRS broth. The cultures were preserved in $20 \%$ glycerol at $-80^{\circ} \mathrm{C}$.

\section{Chemicals}

All the chemicals, except skimmed milk and Tween-80 were obtained form Fluka, Switzerland. Skimmed milk (Amul Lite) was obtained from Amul, India. Tween-80 was procured from Sigma, USA.

\section{Quantification of nisin}

Nisin quantification was done by agar diffusion assay.

\section{Step 1}

MRS broth $(2 \%$, w/v) along with $0.1 \%(\mathrm{v} / \mathrm{v})$ Tween-80 was autoclaved at $121^{\circ} \mathrm{C}$ for 15 minutes. Frozen cultures of S.agalactae $(500 \mu \mathrm{l})$ were inoculated in the sterilized medium and incubated at $37^{\circ} \mathrm{C}, 180 \mathrm{rpm}$ till the optical density reached to $0.8 \pm 0.2$.

\section{Step 2}

MRS broth $(2 \%$, w/v) along with $0.1 \%$ (v/v) Tween- 80 and $1 \%$ agar powder was autoclaved at $121^{\circ} \mathrm{C}$ for 15 minutes. After cooling to $45 \pm 5^{\circ} \mathrm{C}$, S.agalactae was added in such a way that the final optical density becomes 0.001. Approximately $30 \pm 1 \mathrm{ml}$ was poured on to the Petri plates. The media was allowed to solidify for one hour and 5 $\mathrm{mm}$ wells were created using a gel puncture.

\section{Step 3}

Different concentrations of standard nisin were prepared with acidic water and filtered through $0.22 \mu \mathrm{m}$ syringe filter. Standard samples were loaded in the wells and incubated for $20 \mathrm{~h}$ and then diameters were measured and a standard curve was plotted.

\section{Optical density measurement}

To measure the optical density, $1 \mathrm{ml}$ sample was taken from the flask under aseptic conditions and centrifuged at 10,800g for 15 minutes. Supernatant was discarded and $1 \mathrm{ml}$ of water for injection (WFI) was added to the cell pellet, vortexed and was centrifuged again to remove the turbid particles. The washing step was repeated twice and finally $1 \mathrm{ml}$ of WFI was added and mixed. Optical density was measured at $600 \mathrm{~nm}$ taking WFI as blank.

Optimization of fermentation process Experiments were carried out in $250 \mathrm{ml}$ Erlenmeyer flask containing $50 \mathrm{ml}$ of medium. Flasks were autoclaved at $121^{\circ} \mathrm{C}$ for 15 minutes. After cooling, inoculum was added to the flasks in such a way that the initial optical density becomes 0.01 . The flasks were incubated in an incubator shaker for $20 \mathrm{~h}$ and then the contents were centrifugation at $10,800 \mathrm{~g}$ for 30 minutes.

\section{Inoculum preparation}

MRS broth $(2 \%, \mathrm{w} / \mathrm{v})$ with $0.1 \%(\mathrm{v} / \mathrm{v})$ Tween-80 was autoclaved at $121^{\circ} \mathrm{C}$ for 15 minutes. Frozen culture of L. lactis $(500 \mu \mathrm{l})$ was inoculated to the sterilized medium and incubated at $37^{\circ} \mathrm{C}$ and 180 rpm in an incubator shaker till the optical density reached to $1.0 \pm 0.2$.

\section{Optimization of MRS broth concentration}

Different concentrations of MRS broth $(1,2,4,6$, 8 and $10 \%,(w / v))$ were used for the optimization of best concentration for the growth of L.lactis and nisin production by incubating for $20 \mathrm{~h}$ as described earlier. For quantification of nisin, supernatant was filtered by $0.22 \mu \mathrm{m}$ syringe filter and loaded in the wells as given in materials and methods.

\section{Optimization of skimmed milk concentration}

To increase the production of nisin, different concentrations of milk $(0.05,0.1,0.3,0.5,0.7$ and $0.9 \%,(\mathrm{v} / \mathrm{v}))$ were supplemented to the MRS medium. Fermentation was carried out for $20 \mathrm{~h}$ as above.

\section{Effect of temperature on nisin production}

L. lactis was grown at different temperatures (30 and $37^{\circ} \mathrm{C}$ ) in MRS medium along with $0.5 \%(\mathrm{v} / \mathrm{v})$ skimmed milk. Specific growth rate determination of L. lactis and nisin quantification was done as described earlier. 
In order to increase the biomass first, L.lactis was grown at $37^{\circ} \mathrm{C}$ till the optical density reached to 2.0. Afterwards the temperature was shifted to $30^{\circ} \mathrm{C}$, keeping the fermentation time constant i.e. $20 \mathrm{~h}$ from inoculation time.

To increase the biomass, the cells were grown at $37^{\circ} \mathrm{C}$ till the OD reached to 2.0. Afterwards the biomass was aseptically transferred to the fresh medium (composition, same as the previous one). Afterwards fermentation was continued at $30^{\circ} \mathrm{C}$ for $20 \mathrm{~h}$ at $180 \mathrm{rpm}$.

\section{Growth studies}

L. lactis was grown 30 and $37^{\circ} \mathrm{C}$. Sampling was done at every hour and optical density was measured at $600 \mathrm{~nm}$. Growth curve was prepared by taking Optical density and time interval.

\section{Optimization of agitation}

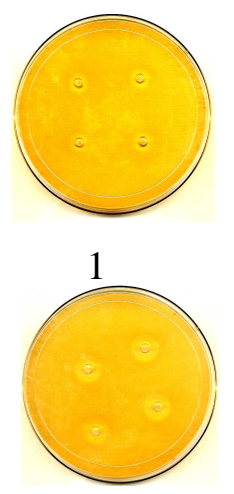

3
In order to optimize the best aeration, L. lactis was grown at 100, 140 and $180 \mathrm{rpm}$ keeping all other parameters constant.

\section{Effect of nisin on nisin production}

Different concentration of nisin $(0.1,0.15,0.20$, 0.25.0.30, $0.35 \mu \mathrm{g} / \mathrm{ml}$ ) was added to optimize the best concentration required for maximum nisin yield. Flasks were incubated as above for $20 \mathrm{~h}$.

\section{RESULTS AND DISCUSSION}

\section{Quantification of nisin}

Figure 1 shows the zone of inhibition formed. It was found that at lower concentration of nisin linearity was achieved.

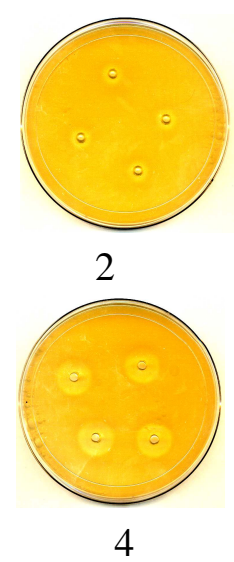

Figure1 - Inhibition zone formed by different concentrations of nisin.

\section{Optimization of MRS concentration}

MRS and M17 media have been reported as suitable media for promoting growth and nisin production with L. lactis (Cheig et al., 2002). Various percentages of MRS were taken in order to optimize the best concentration of MRS not only for its growth but also for nisin production. Among the various percentages used, the maximum growth was seen in 4 and $6 \%$ as shown in Figure 2. Average specific growth rate, i.e. $\mu_{\text {average }}$ was calculated and it was found that $L$. lactis attained $\mu_{\text {average }}$ of $\left(0.59 \mathrm{~h}^{-1}, 0.58 \mathrm{~h}^{-1}\right)$ in 4 and $6 \%$ MRS, respectively. Higher and lower concentrations of MRS broth resulted in slow growth rate and poor nisin yield which might be due to substrate limitation in former and substrate inhibition in later. Initial $\mathrm{pH}$ of the medium was adjusted to 6.3 but during the growth of L.lactis, the $\mathrm{pH}$ of media changed drastically. The final $\mathrm{pH}$ of the broth was measured and found to be 4.0, 4.3, 4.7, 5.0, 5.2 and 5.7 for $1,2,4,6,8$ and $10 \%$ MRS broth, respectively. The difference between the initial and final $\mathrm{pH}$ was calculated for all the flasks (Fig. 3) which was 2.3, 2.0, 1.6, 1.3, 1.1 and 0.6 , respectively. The rationale for decrease in the $\mathrm{pH}$ was either decreased buffering capacity of the medium due to more dilution or higher buffering capacity at increased MRS concentration, when biomass and lactate productions were lower. 


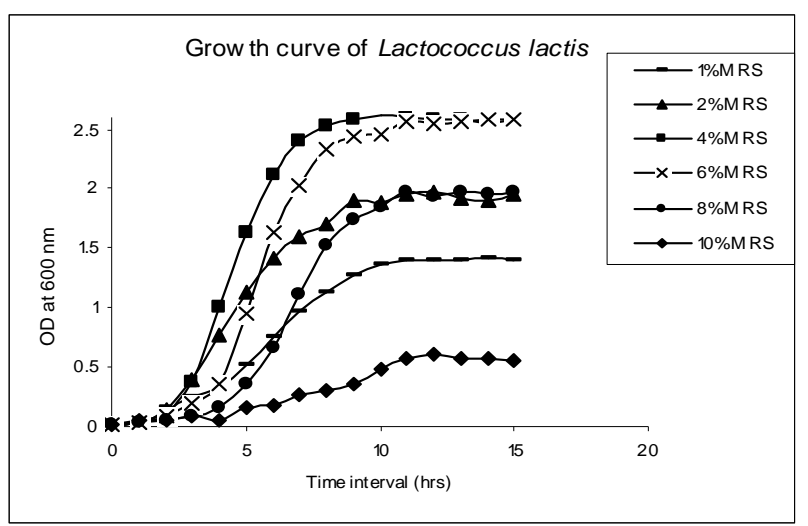

Figure 2 - Growth pattern of L .lactis in different concentration of MRS broth at $37^{\circ} \mathrm{C}$ and 180 RPM.

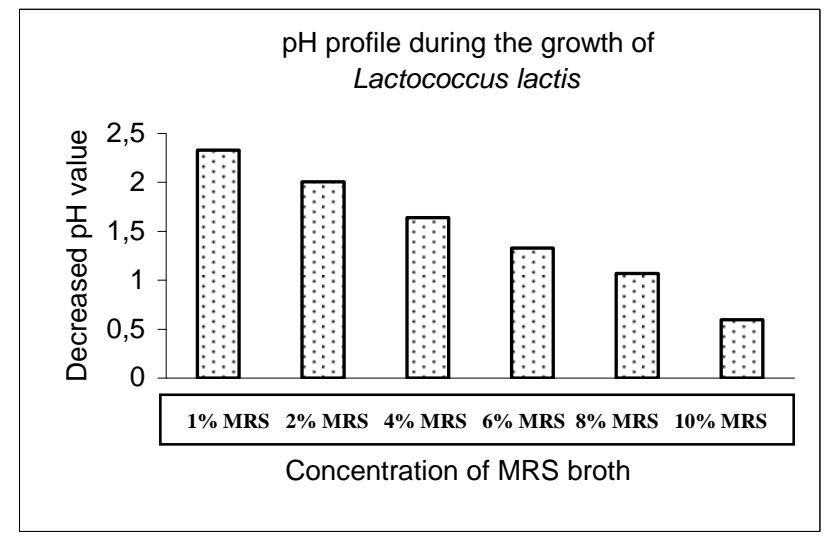

Figure 3 - The pH decreased during the growth of Lactococcus lactis in different concentration of MRS broth.

\section{Optimization of skimmed milk concentration}

Jojala et al., (2004) found that 25\% MRS or $25 \%$ M17 supplemented with $25 \%$ milk favored the nisin production and released it into the media at final $\mathrm{pH}$ between 4.6 and 4.8. The $25 \%$ milk concentration showed a positive influence on the formation and release of nisin by the cells and appeared to be the best. It was found that nisin production increased consistently from first to fifth transfer in M17+milk medium. Enhanced nisin yield was obtained in 6\% MRS broth as compared to $4 \%$ MRS broth (Table 1). The $0.5 \%$ milk in combination with $6 \%$ MRS favored maximum nisin production in comparison to other concentrations of milk (Table 1).

\section{Effect of temperature on nisin production}

It was found that at $30^{\circ} \mathrm{C}$ more nisin and less biomass were produced, while at $37^{\circ} \mathrm{C}$ more biomass and less nisin was produced (Table 1).
Growing L.lactis first at $37^{\circ} \mathrm{C}$ till $2.0 \mathrm{OD}$ and shifting the temperature to $30^{\circ} \mathrm{C}$ did not favor much nisin production in comparison to the constant growth at $30^{\circ} \mathrm{C}$. Similarly, transferring the cells to $30^{\circ} \mathrm{C}$ when the $\mathrm{OD}$ reached to 2.0 along with the change of medium $(6 \% \mathrm{MRS}$ and $0.5 \%$ milk) didn't favor increase in nisin production (Table 1).

\section{Growth studies}

When L. lactis was grown at $37^{\circ} \mathrm{C}$, more biomass was obtained (final O.D 3.4), whereas L. lactis grown at $30^{\circ} \mathrm{C}$ resulted in poor yield of biomass (final O.D 2.55).

\section{Optimization of agitation}

It was found that the production of nisin increased significantly, when $L$. lactis was grown at 100 RPM (Table 1). 
$\underline{\text { Table } 1 \text { - Nisin production }(20 \mathrm{~h}) \text { under different physiochemical parameters. }}$

\begin{tabular}{|c|c|c|c|}
\hline Sl no & Media composition & Growth conditions & $\begin{array}{c}\text { nisin yield } \\
\mu \mathrm{g} / \mathrm{ml}\end{array}$ \\
\hline 1 & $1 \% \mathrm{MRS}$ & $37^{\circ} \mathrm{C}, 180 \mathrm{RPM}$ & 0 \\
\hline 2 & $2 \% \mathrm{MRS}$ & $37^{\circ} \mathrm{C}, 180 \mathrm{RPM}$ & 0 \\
\hline 3 & $4 \% \mathrm{MRS}$ & $37^{\circ} \mathrm{C}, 180 \mathrm{RPM}$ & 0.56 \\
\hline 4 & $6 \% \mathrm{MRS}$ & $37^{\circ} \mathrm{C}, 180 \mathrm{RPM}$ & 1.77 \\
\hline 5 & $8 \% \mathrm{MRS}$ & $37^{\circ} \mathrm{C}, 180 \mathrm{RPM}$ & 0 \\
\hline 6 & $10 \% \mathrm{MRS}$ & $37^{\circ} \mathrm{C}, 180 \mathrm{RPM}$ & 0 \\
\hline 7 & $6 \% \mathrm{MRS}$ & $30^{\circ} \mathrm{C}, 180 \mathrm{RPM}$ & 33.33 \\
\hline 8 & $6 \%$ MRS $+0.05 \%$ milk & $37^{\circ} \mathrm{C}, 180 \mathrm{RPM}$ & 1.88 \\
\hline 9 & $6 \% \mathrm{MRS}+0.1 \%$ milk & $37^{\circ} \mathrm{C}, 180 \mathrm{RPM}$ & 5.1 \\
\hline 10 & $6 \% \mathrm{MRS}+0.3 \%$ milk & $37^{\circ} \mathrm{C}, 180 \mathrm{RPM}$ & 8.6 \\
\hline 11 & $6 \% \mathrm{MRS}+0.5 \%$ milk & $37^{\circ} \mathrm{C}, 180 \mathrm{RPM}$ & 31.25 \\
\hline 12 & $6 \% \mathrm{MRS}+0.7 \%$ milk & $37^{\circ} \mathrm{C}, 180 \mathrm{RPM}$ & 20.83 \\
\hline 13 & $6 \% \mathrm{MRS}+0.9 \%$ milk & $37^{\circ} \mathrm{C}, 180 \mathrm{RPM}$ & 10.42 \\
\hline 14 & $6 \% \mathrm{MRS}+0.5 \%$ milk & $37^{\circ} \mathrm{C}, 180 \mathrm{RPM}$ (biomass transfer at OD 2.0 along with temp $30^{\circ} \mathrm{C}$ ) & 18.75 \\
\hline 15 & $6 \% \mathrm{MRS}+0.5 \%$ milk & $37^{\circ} \mathrm{C}, 180 \mathrm{RPM}$ (at OD 2.0 and temp changes to $30^{\circ} \mathrm{C}$ ) & 9.38 \\
\hline 16 & $6 \% \mathrm{MRS}+0.5 \%$ milk & $30^{\circ} \mathrm{C}, 140 \mathrm{RPM}$ & 96.88 \\
\hline 17 & $6 \% \mathrm{MRS}+0.5 \%$ milk & $30^{\circ} \mathrm{C}, 100 \mathrm{RPM}$ & 121.88 \\
\hline 18 & $6 \% \mathrm{MRS}+0.5 \%$ milk & $30^{\circ} \mathrm{C}, 100 \mathrm{RPM}$, initial concentration of nisin $0.1 \mu \mathrm{g} / \mathrm{ml}$ & 149.9 \\
\hline 19 & $6 \% \mathrm{MRS}+0.5 \%$ milk & $30^{\circ} \mathrm{C}, 100 \mathrm{RPM}$, initial concentration of nisin $0.15 \mu \mathrm{g} / \mathrm{ml}$ & 206.1 \\
\hline 20 & $6 \% \mathrm{MRS}+0.5 \%$ milk & $30^{\circ} \mathrm{C}, 100 \mathrm{RPM}$, initial concentration of nisin $0.2 \mu \mathrm{g} / \mathrm{ml}$ & 149.8 \\
\hline 21 & $6 \%$ MRS $+0.5 \%$ milk & $30^{\circ} \mathrm{C}, 100 \mathrm{RPM}$, initial concentration of nisin $0.25 \mu \mathrm{g} / \mathrm{ml}$ & 149.75 \\
\hline 22 & $6 \% \mathrm{MRS}+0.5 \%$ milk & $30^{\circ} \mathrm{C}, 100 \mathrm{RPM}$, initial concentration of nisin $0.3 \mu \mathrm{g} / \mathrm{ml}$ & 99.7 \\
\hline 23 & $6 \% \mathrm{MRS}+0.5 \%$ milk & $30^{\circ} \mathrm{C}, 100 \mathrm{RPM}$, initial concentration of nisin $0.35 \mu \mathrm{g} / \mathrm{ml}$ & 99.65 \\
\hline
\end{tabular}

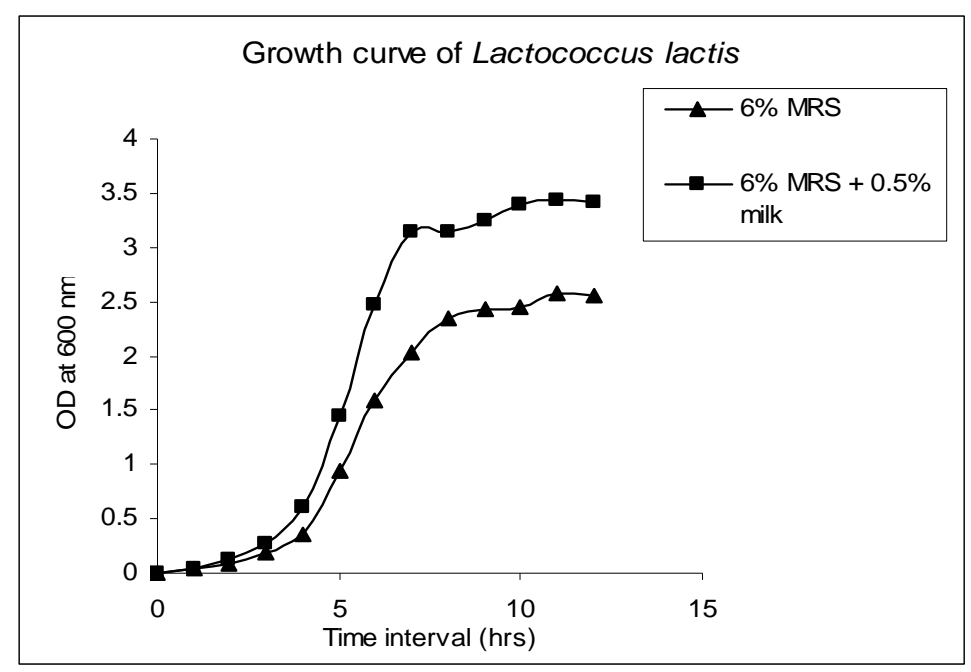

Figure 4 - Growth pattern of L.lactis in 6\% MRS and, 6\% MRS supplemented with $0.5 \%$ skimmed milk at $37^{\circ} \mathrm{C}$ at $100 \mathrm{RPM}$. 


\section{Effect of nisin on nisin production}

Nisin has an autoregulatory system, i.e., it induces its own expression. The presence of nisin in media induces the autophosphorylation of histidine kinase that activates the transcription of nisin structural gene (Chandrapati and O'Sullivan 1999, 2002). The gene (nisin) encoding the desired protein/enzyme by the addition of auto-inducer nisin to the growth medium (de Ruyter et al. 1996b, Kuipers et al. 1998, Kleerebezem et al. 2000). Among different concentrations of nisin, $0.15 \mu \mathrm{g} / \mathrm{ml}$ was the most suitable concentration for the best yield of nisin (Table 1).

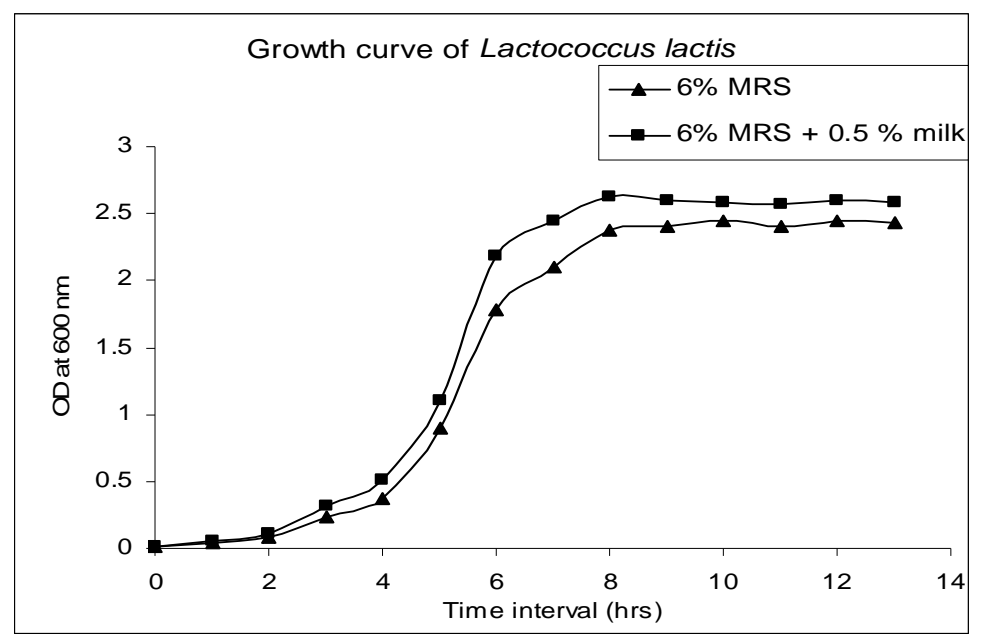

Figure 5 - Growth pattern of L.lactis in 6\% MRS and, 6\% MRS supplemented with $0.5 \%$ skimmed milk at $30^{\circ} \mathrm{C}$ at 100 RPM (table 1).

\section{CONCLUSION}

Quantification of nisin by agar diffusion assay gave best result at its lower concentration. MRS (6\%) and $0.5 \%$ milk with $0.15 \mu \mathrm{g} / \mathrm{ml}$ of nisin were the best parameters for nisin production. Among the physical parameters, $30^{\circ} \mathrm{C}$ and $100 \mathrm{rpm}$ for 20 $\mathrm{h}$ were the best. The temperature of $30^{\circ} \mathrm{C}$ favored the production of nisin whereas $37^{\circ} \mathrm{C}$ enhanced the biomass production.

\section{ACKNOWLEDGEMENT}

The work was financially supported by INTAS Biopharmaceutical Ltd., Ahmedabad. We thank L.Gupta, R.Jena, D.Dave, V.Kumar, V.Parikh, G.Mehta, K.Patel for their technical support.

\section{REFERENCES}

Chandrapati, S., O’Sullivan, D.J. (1999), Nisin independent induction of the nisA promoter in Lactococcus lactis during growth in lactose or galactose. FEMS Microbiol. Lett. 170, 191-198.

Chandrapati, S., O'Sullivan, D.J. (2002), Characterization of the promoter regions involved in galactose- and nisin-mediated induction of the nisA gene in Lactococcus lactis ATCC 11454. Mol. Microbiol., 2, 467-477.

Cheig, C. I., Choi, H. J., Park, H., Kim, T.S., Hwang, J. K., Pyun, Y. R. (2002), Influence of growth condition on the production of a nisin like bacteriocin by lactococcus lactis subsp lactis A164 isolated kimchi.J.Biotechnnol.,95, 225-235.

de Ruyter, P.G.G.A., Kuipers, O.P., de Vos, W.M. (1996), Controlled gene expression systems for Lactococcus lactis with the food grade inducer nisin. Appl. Environ. Microbiol. 62, 3662-3667. 
Delves-Broughton J, Blackburn P, Evans RJ, Hugenholtz, J. (1990), Application of bacteriocin nisin. Antonie Van Leeuwenhoek, Rev., 69, 193-202.

Hensen JN, chung Y, Liu, W. (1991), Biosynthesis and mechanism of the action of nisin and subtilin. ESCOM science Publishers In: Nisin and novel antibiotics, Leiden. pp.287-302.

Hurst, A. (1967), Function of nisin and nisin like basic proteins in the growth cycle of streptococcus lactis. Nature, 214, 1232-1234.

Jozala,A.F, de Lencastre Novaes, L.C., Cholewa, O., Dante, M., Vessoni Penna, T.C. (2005), Increase of nisin production by Lactococcus lactis in different media. African Journal of Biotechnology.Vol 4 (3), 262-265.

Kleerebezem, M., Hols, P., Hugenholtz, J. (2000), Lactic acid bacteria as a cell factory: rerouting of carbon metabolism in Lactococcus lactis by metabolic engineering. Enzyme Microb. Technol., 26, 840-848.

Kuipers, O.P., de Ruyter, P.G.G.A., Kleerebezem, M., de Vos, W.M. (1998) Quorum sensing-controlled gene expression in lactic acid bacteria. J. Biotech., 64, 15-21.

Monteville, T.J. and Chen, Y. (1998), Mechanism of action pediocin and nisin based germicidal formulation on teat skin of live cows. J. Dairy Sci., $\mathbf{7 5}, \mathbf{3 1 8 5}-3190$.
Thomas, L.V., Ingram, R.E., Bevis, H.E., Davies, A, Milne, C.F., Delves-Broughton.(2002), Effective use of nisin to control Bacillus and Clostridium spoilage of a pasteurized mashed potato product. J.Food.Protect, 65:1580-1585.

Turner, S.R., Love, R.M., and Lyons, K.M. (2004), An in vitro investigation of the antimicrobial effect of nisin on root canals and canal wall redicular dentine. J.Int. Endodontic., 37, 664-671.

Vessoni Penna T.C., Moraes, D.A. (2002), The effect of nisin on growth kinetics from activated Bacilllus cereus spores in cooked rice and milk, J.Food Protec., 65, 419-422.
Received: April18, 2007;
Revised: January 28, 2008; Accepted: June 12, 2009. 